The FASEB Journal express article 10.1096/fj.02-0885fje. Published online April 8, 2003.

\title{
Activation of neuropeptide $Y$ receptors is neuroprotective against excitotoxicity in organotypic hippocampal slice cultures
}

Ana P. Silva*, Paulo S. Pinheiro*, Arsélio P. Carvalho*, Caetana M. Carvalho*, Birthe Jakobsen ${ }^{\ddagger}$, Jens Zimmer", and João O. Malva*,§

*Center for Neuroscience of Coimbra, Department of Zoology, University of Coimbra, 3004-517 Coimbra, Portugal; ${ }^{\S}$ Institute of Biochemistry, Faculty of Medicine, University of Coimbra, 3004-504 Coimbra, Portugal; and Department of Anatomy and Neurobiology, University of Southern Denmark - Odense, DK-5000 Odense C, Denmark

Corresponding author: João Malva, Institute of Biochemistry, Faculty of Medicine, University of Coimbra, 3004-504 Coimbra, Portugal.E-mail: jomalva@cnc.cj.uc.pt

\section{ABSTRACT}

Glutamate and NPY have been implicated in hippocampal neuropathology in temporal lobe epilepsy. Thus, we investigated the involvement of NPY receptors in mediating neuroprotection against excitotoxic insults in organotypic cultures of rat hippocampal slices. Exposure of hippocampal slice cultures to $2 \mu \mathrm{M}$ AMPA ( $\alpha$-amino-3-hydroxy-5-methyl-isoxazole-4propionate) induced neuronal degeneration, monitored by propidium iodide uptake, of granule cells and CA1 pyramidal cells. For dentate granule cells, selective activation of Y1, Y2, or Y5 receptors with $1 \mu \mathrm{M}\left[\mathrm{Leu}^{31}, \mathrm{Pro}^{34}\right] \mathrm{NPY}, 300 \mathrm{nM}$ NPY13-36 or $1 \mu \mathrm{M} 500 \mathrm{nM}$ NPY(19-23)(Gly ${ }^{1}, \mathrm{Ser}^{3}, \mathrm{Gln}^{4}, \mathrm{Thr}^{6}, \mathrm{Ala}^{31}, \mathrm{Aib}^{32}, \mathrm{Gln}^{34}$ )-PP, respectively, had a neuroprotective effect against AMPA, whereas only the activation of Y2 receptors was effective for CA1 pyramidal cells. When the slice cultures were exposed to $6 \mu \mathrm{M}$ kainate, the CA3 pyramidal cells displayed significant degeneration, and in this case the activation of Y1, Y2, and Y5 receptors was neuroprotective. For the kainic acid-induced degeneration of CA1 pyramidal cells, it was again found that only the Y2 receptor activation was effective. Based on the present findings, it was concluded that Y1, Y2, and Y5 receptors effectively can modify glutamate receptor-mediated neurodegeneration in the hippocampus.

Key words: NPY • AMPA • kainate $\bullet$ neuroprotection $\bullet$ neurodegeneration

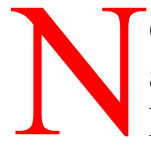
europeptide Y (NPY) is a 36-amino-acid peptide abundantly distributed in the brain and associated with a number of physiological and pathological conditions (1). This peptide has been shown to modulate anxiety, pain, memory, eating behavior, and many other functions in the central, as well as in the peripheral, nervous systems $(1,2)$. Another significant role of NPY that has become evident during the past decade is regulation of seizure activity (3).

At least five NPY receptor subtypes have been identified based on different pharmacological profiles: Y1, Y2, Y4, Y5, and y6 (4). A putative Y3 receptor has also been identified (5). $\left[\mathrm{Leu}^{31}, \mathrm{Pro}^{34}\right] \mathrm{NPY}$ and NPY13-36 have been proposed to be particularly selective agonists for 
Y1 and Y2 receptors, respectively (6). More recently, Cabrele et al. (7) developed the first Y5 receptor-selective analog of NPY, $\left[\mathrm{Ala}^{31}, \mathrm{Aib}^{32}\right] \mathrm{NPY}$. Also, there are currently several NPY receptor antagonists available: BIBP3226 binds and specially inhibits the Y1 receptor subtype (8), whereas BIIE0246 is a potent and selective Y2 receptor antagonist (9), and L-152,804 an Y5 receptor antagonist (10).

In the hippocampus, Y1 and Y2 receptors are highly expressed (11). Receptors of the Y1 subtype are preferentially located in granule cells of the dentate molecular layer, whereas Y2 receptors are expressed at high concentrations in the mossy fiber and Schaffer collateral fields (12). Moreover, Y5 receptor binding sites can also be found in the strata oriens and radiatum of the CA3 and CA1 areas $(13,14)$. Presently, there is evidence for the involvement of these three NPY receptors subtypes in epilepsy. The activation of Y2 receptors suppresses seizure activity in hippocampal slices in vitro (15) and in vivo models (3). In human temporal lobe epilepsy, significant alterations in Y1 and Y2 receptor binding were observed (16). NPY Y5 receptors also seem to be involved in the suppression of seizure activity $(17,18)$. In different animal models of epilepsy, NPY is highly expressed by granule cells and mossy fibers of the hippocampus (19, 20), whereas in normal conditions only GABAergic interneurons express this peptide. Furthermore, knockout mice lacking the NPY gene develop spontaneous seizures and are more susceptible to pentylenetetrazol and kainic acid-induced motor seizures, which are inhibited by intracerebral infusion of NPY (21). Thus, these evidences suggest that NPY-mediated effects may be activated under epileptogenesis and excitotoxicity.

One candidate mechanism for the anticonvulsant properties of NPY is the inhibition of calcium influx $(22,23)$ and glutamate release $(24,23)$. However, in spite of the relevance of the field, the relation between NPY and glutamate is not fully understood. In the present study, we demonstrate that activation of $\mathrm{Y} 1, \mathrm{Y} 2$, and $\mathrm{Y} 5$ receptors can protect against excitotoxic glutamate receptor mediated neurodegeneration in organotypic slice cultures of the rat hippocampus.

\section{MATERIAL AND METHODS}

\section{Organotypic hippocampal slice cultures}

Organotypic hippocampal slice cultures were prepared according to the interface method (25), as modified by Kristensen et al. (26) and Noraberg et al. (27). In brief, after decapitation and removal of the brains of 7-day old Wistar rat pups (Møllegaard, Denmark), the hippocampi were isolated and the middorsal parts sectioned into 350- $\mu$ m-thick slices on a McIlwain tissue chopper. The tissue slices were placed in cold Gey's balanced salt solution (GBSS; Gibco BRL, Life Technologies Ltd., Paisley, Scotland) supplemented with glucose $(6.5 \mathrm{mg} / \mathrm{ml})$ (Merck, Darmstadt, Germany), and separated from excess tissue. The slices were then placed on semiporous membranes with six slices on each membrane insert (diameter $3 \mathrm{~cm}$; Millipore Corp., Bedford, MA, USA), and the inserts transferred to a culture tray (Corning Costar, Corning, NY) with six wells, each containing $1 \mathrm{ml}$ of medium consisting of $25 \%$ inactivated horse serum, 25\% Hank's balanced salt solution (HBSS), and 50\% OPTIMEM medium (all from Gibco BRL), supplemented with D-glucose $(25 \mathrm{mM})$ and L-glutamine $(1 \mathrm{mM})$. The trays were placed in an incubator at $36^{\circ} \mathrm{C}$ with an atmosphere of $5 \% \mathrm{CO}_{2}$ and $95 \%$ humidified air. On the third day and thereafter the medium was changed to chemically defined serum-free Neurobasal 
medium (Gibco BRL), supplemented with D-glucose (25 mM), L-glutamine (1 mM) (Sigma, Vallensbæk Strad, Denmark), and 2\% B-27 supplement (Gibco. BRL). This medium was changed every third or fourth day for 3 weeks before starting the experiments. No antimitotic drugs or antibiotics were used at any stage.

\section{Exposure to excitotoxins and neuropeptide $Y$ agonists/antagonists}

The neurotoxic toxic effects of $2 \mu \mathrm{M}$ AMPA (Sigma) or $6 \mu \mathrm{M}$ kainate (Sigma) were first examined by exposing slice cultures to these drugs for $24 \mathrm{~h}$, in the culture medium (Neurobasal medium, supplemented with D-glucose, L-glutamine, and B-27 supplement). Then, cultures were returned to normal medium, without the drugs (Fig. 1). Digital images of the resulting PtdIns uptake (see below) were obtained $24 \mathrm{~h}$ (day 2) after start of the AMPA or KA exposure, and after a $24 \mathrm{~h}$ recovery period. In some experiments the cultures from the same batch were exposed to AMPA or KA together with $15 \mu \mathrm{M}$ LY303070, a selective noncompetitive AMPA receptor antagonist (kind gift from Lilly Research Laboratories, Indianapolis, IN). The concentrations of AMPA and KA used in this work were chose based in previous studies $(26,35)$. Briefly, Kristensen et al. (2001) performed dose-dependent excitotoxic studies of different drugs and showed that $3 \mu \mathrm{M}$ AMPA and $8 \mu \mathrm{M}$ KA resulted in high levels of PtdIns uptake in the CA1 and CA3 pyramidal cell layer, respectively. Moreover, NBQX inhibited AMPA- and KA-induced toxicity, with no effect in NMDA-induced toxicity.

To test the putative neuroprotective role of NPY receptors, the cultures were first pre-incubated $(24 \mathrm{~h})$ with the selective Y1, Y2, or Y5 receptor agonists (1 $\mu \mathrm{M}\left[\mathrm{Leu}^{31}\right.$,Pro $\left.\left.{ }^{34}\right] \mathrm{NPY}\right), 300 \mathrm{nM}$ NPY13-36 or 500 nM NPY(19-23)-(Gly $\left.{ }^{1}, \mathrm{Ser}^{3}, \mathrm{Gln}^{4}, \mathrm{Thr}^{6}, \mathrm{Ala}^{31}, \mathrm{Aib}^{32}, \mathrm{Gln}^{34}\right)-\mathrm{PP}$, respectively) (all from Bachem Bubendorf, Switzerland). These concentrations were chose based on previous studies performed by us and others $(24,34)$. After the pre-incubation period, cultures were again exposed to the NPY receptor agonists together with $2 \mu \mathrm{M}$ AMPA or $6 \mu \mathrm{M}$ KA (Fig. 1). The same experimental protocol was used to study the effect of $1 \mu \mathrm{M}$ BIBP3226 (Peninsula Laboratories, Belmont, CA) or $1 \mu \mathrm{M}$ BIIE0246 (generous gift from Henri Doods, Boehringer Ingelheim Pharma, Germany), an Y1 or Y2 receptor antagonist, respectively. Digital images of the resulting PtdIns uptake (see below) were obtained after $24 \mathrm{~h}$ (day 1) and $48 \mathrm{~h}$ (day 2) exposure to the NPY receptors agonist and antagonists, as well as after the $24 \mathrm{~h}$ recovery period in normal medium. Moreover, in order to correct for spontaneous increase in PtdIns fluorescence, we subtracted the value for PtdIns uptake at day 0 from the values at day 1, 2, and 3 , and we used the PtdIns values obtained at day 2.

All experiments included control cultures not subjected to glutamate receptor agonists or NPY receptors agonists and antagonists.

\section{Monitoring propidium iodide uptake}

To quantify neuronal damage, the fluorescent marker propidium iodide (PtdIns, 3,8-diamino-5(3-(diethylmethylamino)propyl)-6-phenyl phenanthridinium diiodide; Sigma) was added to the medium, in accordance with an earlier established protocol $(26,27)$. PtdIns is a polar substance that enters only dead or dying cells with damaged cell membranes and binds to DNA with a brightly red, intensified fluorescence $(630 \mathrm{~nm})$, when absorbing blue-green light $(493 \mathrm{~nm})$. This fluorescent marker is basically nontoxic to neurons $(28,29)$ and has been used as an indicator of 
neuronal membrane integrity (30) and cell damage $(29,31)$. Three hours before starting the experiments, $2 \mu \mathrm{M}$ PtdIns was added to the medium for determination of basal cellular uptake, and this concentration was also used in all subsequent medium changes. PtdIns uptake was recorded by fluorescence microscopy [Olympus IMT-2, 4X (Splan FL2)] by using a standard rhodamine filter and digital camera (Sensys KAF 1400 G2, Photometrics, Tucson, AZ) with 0.75 s exposure time. After exposing the cultures to the drugs, digital fluorescent micrographs of the cultures were taken at different time points during the experiments (see Fig. 8), for use in densitometric measurements of the PtdIns uptake in the dentate granule cell layer (DG), CA3, and CA1 pyramidal cell layers. This was performed by delineating the different subfields by using NIH Image 1.64 analysis software (National Institutes of Health, Bethesda, MD).

\section{Morphological preparation and toluidine blue staining}

Organotypic hippocampal slice cultures were prepared and stained as described by Noraberg et al. (27). In brief, at the end of each experiment the cultures were fixed for $1 \mathrm{~h}$ in $4 \%$ phosphate buffered paraformaldehyde (PFA; Fluka), washed for $30 \mathrm{~min}$ in $0.15 \mathrm{M}$ phosphate buffer, and then washed in distilled water for $30 \mathrm{~min}$. After this, a thin and soft brush was used to detached and transferred the slices from the membrane, and each culture was placed on glass slides (cultures from one well on one glass slide) in a droplet of distilled water and left to dry at $4{ }^{\circ} \mathrm{C}$ for a minimum of $24 \mathrm{~h}$ before staining. Then, slices were again washed three times in distilled water; stained with the toluidine blue solution $\left(77 \mathrm{mM} \mathrm{Na}_{2} \mathrm{HPO}_{4}, 2 \mathrm{H}_{2} \mathrm{O}, 67.2 \mathrm{mM}\right.$ citric acid, $3.3 \mathrm{mM}$ toluidine blue) (15 min); dehydrated in 70, 90, and 99\% ethanol (2 min each); cleared in xylene ( 5 min); rehydrated in 99 and $96 \%$ ethanol and distilled water ( 2 min each); again stained in toluidine blue solution (15 min); rinsed three times in distilled water ( 5 min each); dehydrated in 70,96 and $99 \%$ ethanol $(0.5,1.5$, and $5 \mathrm{~min}$, respectively); and finally cleared three times ( $5 \mathrm{~min}$ each) in xylene and mounted in DePex. The stained cultures were analyzed by optical microscopy, under high magnification $(\times 500)$.

\section{Data analysis}

The data are expressed as means \pm SEM. The values \pm SEM are the total number of slices over multiple experiments on different days. Statistical significance was determined by using an ANOVA, followed by Dunnett's or Bonferroni's post-test, as indicated in the figure legends. PtdIns uptake values are expressed as percentage of control and in neuroprotection studies the PtdIns uptake induced by $2 \mu \mathrm{M}$ AMPA or $6 \mu \mathrm{M}$ KA was set to $100 \%$.

\section{RESULTS}

\section{Protection against AMPA-induced neurodegeneration of dentate granule cells and CA1 pyramidal cells by NPY receptor activation}

Exposure of hippocampal slice cultures to $2 \mu \mathrm{M}$ AMPA for $24 \mathrm{~h}$ induced an increase in cellular uptake of propidium iodide (PtdIns), which was particularly evident in the CA1 pyramidal cell layer $(214.0 \pm 24.6 \%$ of control, $n=66)$, and in the dentate granule cell layer $(132.1 \pm 8.3 \%$ of control, $n=66$ ) (Figs. 2A and $\underline{3 \mathrm{~B}}$ ). However, the CA3 pyramidal cells did not display a corresponding statistically significant increase in the PtdIns uptake $(111.1 \pm 4.9 \%$ of control, $n=66$ ) (Fig. 2A). Application of a selective AMPA receptor antagonist (LY303070; $15 \mu \mathrm{M})$ 
allowed us to demonstrate that the neuronal degeneration essentially was due to a selective activation of AMPA receptors, since application of this compound abolished the increased PtdIns uptake induced by AMPA in the dentate granule cell layer $(86.8 \pm 3.4 \% ; n=14)$ and in CA1 pyramidal cell layer $(102.2 \pm 16.0 \% ; n=14)$ (Fig. 2A).

The putative neuroprotective role of different NPY receptors against AMPA receptor- mediated excitotoxicity in dentate granule cells and CA1 pyramidal cells were investigated. In these experiments, the mean value of PtdIns uptake in all subfields after $24 \mathrm{~h}$ of exposure to $2 \mu \mathrm{M}$ AMPA ( $n=66$ ) was set to $100 \%$, representing maximal PtdIns uptake (Fig. 2B, 2C, 4A and 4B). After pre-exposure $(24 \mathrm{~h})$ to the different selective NPY receptors agonists, followed by $24 \mathrm{~h}$ of co-exposure with $2 \mu \mathrm{M}$ AMPA, we found that $1 \mu \mathrm{M}\left[\mathrm{Leu}^{31}\right.$,Pro $\left.{ }^{34}\right] \mathrm{NPY}$, an Y1 receptor agonist, reduced the PtdIns uptake to $44.9 \pm 16.7 \%(n=18)$ in the dentate granule cell layer (Fig. $2 \mathrm{~B})$, without having a statistically significant effect on CA1 pyramidal cells $(82.0 \pm 10.9 \%, n=18)($ Fig. 2C). Regarding activation of Y2 receptors, the neuroprotective effect of the selective agonist (300 nM NPY13-36) was very significant with a reduction of PtdIns uptake to $34.5 \pm 20.9 \%$ $(n=19)$ (Figs. 2B and $\underline{3 \mathrm{C}}$ ) in the dentate granule cell layer and 39.0 $\pm 6.5 \%(n=19)$ (Figs. 2C and $\underline{3 C})$ in the CA1 pyramidal cell layer. In the presence of $500 \mathrm{nM}$ NPY(19-23)-( $\left.\mathrm{Gly}^{1}{ }^{,} \mathrm{Ser}^{3}, \mathrm{Gln}^{4}, \mathrm{Thr}^{6}, \mathrm{Ala}^{31}, \mathrm{Aib}^{32}, \mathrm{Gln}^{34}\right)$-PP, known as an Y5 receptor agonist, the AMPA-induced PtdIns uptake was reduced to $59.9 \pm 12.7 \%(n=35)$ in dentate granule cell layer $(\underline{\text { Fig. } 2 \mathrm{~B}})$, whereas no significant inhibition was observed in CA1 pyramidal cell layer $(80.5 \pm 8.9 \%, n=35)$ (Fig. $2 \mathrm{C}$ ).

To better characterize the selectivity of the neuroprotective effects mediated by NPY receptors, we also tested the effect of Y1 and Y2 receptor antagonists. For the dentate granule cell layer, addition of $1 \mu \mathrm{M}$ BIBP3226 (Y1 receptor antagonist) or $1 \mu \mathrm{M}$ BIIE0246 (Y2 receptor antagonist), essentially abolished the inhibition induced by Y1 $(104.7 \pm 16.9 \%, n=21)$ or Y2 $(82.8 \pm 11.1 \%, n=12)$ receptor agonists (Fig. 4A). Corresponding to the lack of effect of the NPY Y1 receptor agonist in CA1, only the Y2 receptor antagonist BIIE0246 was effective in preventing the neuroprotective effect of $300 \mathrm{nM}$ NPY13-36 $(93.2 \pm 1.9 \%, n=12)$ (Fig. 4B).

Cultures exposed to $2 \mu \mathrm{M}$ AMPA for $24 \mathrm{~h}$, followed by $24 \mathrm{~h}$ recovery, also showed a significant neurodegeneration when evaluated by toluidine blue staining, in particular in the CA1 pyramidal cells, where neurons with apoptotic-like morphology were found. Indeed, it was possible to observe cell shrinkage and nuclear condensation (Fig. 5B), which was prevented in the presence of the Y2 receptor agonist (NPY13-36) (Fig. 5C).

\section{Protection against kainic acid-induced neurodegeneration of CA3 and CA1 pyramidal cells by NPY receptor activation}

As previously reported, the toxicity induced by $6 \mu \mathrm{M}$ kainate followed a different pattern from that observed in the presence of $2 \mu \mathrm{M}$ AMPA $(26,35)$. Exposure of hippocampal slice cultures to $6 \mu \mathrm{M}$ kainate for $24 \mathrm{~h}$ induced PtdIns uptake in the CA1 (122.6 $\pm 12.8 \%$ of control, $n=33)$ and in particular in the CA3 $(161.4 \pm 12.7 \%$ of control, $n=33)$ pyramidal cell layer, whereas no increase PtdIns uptake was found in the dentate granule cell layer $(105.1 \pm 4.4 \%, n=33)$ (Figs. 6A and $7 \mathrm{~B}$ ). The neurodegeneration in CA1 and CA3 was clearly mediated by kainate receptors, since $15 \mu \mathrm{M}$ of the AMPA receptor antagonist, LY303070, was unable to significantly prevent the PtdIns uptake induced by $6 \mu \mathrm{M}$ kainate in both cell layers $(131.0 \pm 5.5 \%$ and $138.8 \pm 17.0 \%$ of control, respectively; $n=14$ ) (Fig. 6A). 
In accordance with the neuroprotective effect mediated by Y2 receptors against AMPA-induced toxicity, in CA only activation of Y2 receptors inhibited the kainic acid-induced PtdIns uptake (76.6 $\pm 4.8 \%, n=35)$ (Fig. 6B; $6 \mu \mathrm{M}$ kainate-induced PtdIns uptake set to $100 \%$ ). In contrast, selective activation of Y1, Y2, and Y5 receptors prevented the increase in the kainic acidinduced PtdIns uptake in the CA3 pyramidal cell layer (Fig. 6C). Exposure to $1 \mu \mathrm{M}$ $\left[\mathrm{Leu}^{31}, \mathrm{Pro}^{34}\right] \mathrm{NPY}, \quad 300 \quad \mathrm{nM} \quad \mathrm{NPY} 13-36$ or 500 nM NPY(19-23)$\left(\mathrm{Gly}^{1}, \mathrm{Ser}^{3}, \mathrm{Gln}^{4}, \mathrm{Thr}^{6}, \mathrm{Ala}^{31}, \mathrm{Aib}^{32}, \mathrm{Gln}^{34}\right)$-PP reduced the kainic acid-induced PtdIns uptake to $67.8 \pm 13.4 \%(n=21), 64.4 \pm 3.5 \%(n=35)$ or $62.7 \pm 3.6 \%(n=18)$, respectively (Figs. 6C, $\underline{7 C}$, and 7D).

Evaluation of the cultures exposed to $6 \mu \mathrm{M}$ kainate for $24 \mathrm{~h}$ followed by $24 \mathrm{~h}$ recovery by toluidine blue staining (Fig. $8 \mathrm{~B}$ ) indicated strong degenerative changes, especially in the CA3 pyramidal cell layer, where swollen neurons with a necrotic-like morphology were observed (Fig. 8B). Also, these structural changes were prevented in the presence of the Y2 receptor agonist (NPY13-36) (Fig. 8C).

\section{DISCUSSION}

Using organotypic slice cultures of rat hippocampus, we investigated the putative neuroprotective role of NPY receptors against excitotoxic glutamate receptor mediated neurodegeneration and found that NPY Y1, Y2, and Y5 receptors played a neuroprotective role in AMPA and kainic acid-induced neuronal cell death.

\section{AMPA and kainate-induced excitotoxicity}

The excitotoxic effect caused by activation of ionotropic glutamate receptors has been studied in various in vivo (34) and in vitro models $(35,29)$. In agreement with previous studies, we observed that hippocampal slice cultures treated with AMPA $(2 \mu \mathrm{M})$ or kainate $(6 \mu \mathrm{M})$ display selective degeneration of CA1 (28) or CA3 pyramidal cells (36), respectively. Indeed, previous reports demonstrated that the CA3 subregion is particularly rich in receptors with high affinity to kainate (37), and that these receptors are involved in CA3 pyramidal cell degeneration under excitotoxic conditions $(37,38)$. However, in several models, the pharmacological dissection of active AMPA and kainate receptors was complicated by the similar agonist activity of AMPA and kainate at both receptors. Using a noncompetitive antagonist of AMPA receptors, GYKI53655, it was possible to unmask functional activity of kainate receptors (39). In the present work, the selective involvement of AMPA and kainate receptors in the excitotoxicity caused by AMPA or kainate was investigated further by pretreating the cultures with LY303070, an AMPA receptor antagonist [(-) enantiomer of GYKI53655]. We observed that the PtdIns uptake induced by AMPA $(2 \mu \mathrm{M})$ was completely prevented in the presence of LY303070. In slice cultures treated with kainate $(6 \mu \mathrm{M})$, LY303070 did not, however, significantly prevent the kainate-induced toxicity, suggesting that the toxicity mediated by $2 \mu \mathrm{M}$ AMPA or $6 \mu \mathrm{M}$ kainate was due to selective activation of AMPA or kainate receptors, respectively.

A previous work from our laboratories has already extensively characterized the excitotoxic profiles of AMPA, KA, and NMDA in organotypic hippocampal slice cultures (28). The authors showed that even high concentrations of MK-801 $(10 \mu \mathrm{M})$, an NMDA receptor antagonist, did not protect against the degeneration caused by $3 \mu \mathrm{M}$ AMPA or $8 \mu \mathrm{M}$ KA (28), indicating that the 
PtdIns uptake observed in these conditions, was not mediated by NMDA receptors. Moreover, long-term exposure to AMPA induces substantial neuronal death involving apoptotic-like morphology (40), while kainic acid-induced seizures result in necrotic-like cell death (41). Our results are in accordance with these studies, since the morphology observed after treating the cultures with AMPA or kainate, respectively, also shows similar cell death patterns (Figs. 5 and 8). However, a clear distinction between patterns of cell death need more refined methods and is complicated by the variety of mechanism involved during an excitotoxic insult (42). Exposure of neurons to excitotoxins predominantly induced apoptosis or necrosis, and this appears to depend on the duration and intensity of exposure (42).

\section{Neuroprotection by NPY receptor activation}

Several studies show that NPY can inhibit epileptiform activity in the rat hippocampus (24). Moreover, epileptic seizures result in extensive increase in extracellular glutamate and NPY mRNA expression (19), indicating that NPY-mediated effects may be activated under epileptogenesis and excitotoxicity. In this study, we further investigated the putative neuroprotective role of NPY receptor activation during hyperactivation of AMPA and kainate receptors in organotypic hippocampal slice cultures. In dentate granule cell layer, activation of Y2 receptors played the most important neuroprotective role when compared with both Y1 and Y5 receptors. This corresponds with our previous findings that Y2 receptor activation inhibits glutamate release in this subregion (23), despite a relatively lower expression of these receptors (11). Other studies have shown that NPY inhibits glutamatergic excitation in the rat dentate gyrus (43) and in epileptic human dentate gyrus (44). Activation of Y1 and Y5 receptors is also neuroprotective for dentate granule cells in accordance with other studies $(15,18,45)$. Moreover, McQuiston et al. (46) reported that $\mathrm{Y} 1$ receptors inhibit $N$-type $\mathrm{Ca}^{2+}$ currents in granular cells, whereas we previously have reported that these receptors inhibit glutamate release in dentate gyrus synaptossomes (23). In rat neocortical neurons, Bacci et al. (47) showed that NPY elicits a long-lasting decrease in evoked EPSCs and decrease evoked monosynaptic IPSCs in GABAergic interneurons, which suggest that this neuropeptide has differential effects on different neuronal subtypes.

Concerning the role of NPY Y5 receptors, Marsh et al. (18) used Y5R-deficient mice to demonstrate that Y5 receptors were involved in mediating NPY's inhibitory actions in the mouse hippocampus. Recently, Cabrele et al. (7) developed the first Y5 receptor-selective agonist, and by using this we identified a specific Y5 receptor-like neuroprotection of dentate granule cells and CA3 pyramidal cells in the present study. In CA1, we only observed significant neuroprotective effects mediated by the activation of $\mathrm{Y} 2$, but not $\mathrm{Y} 1$ or $\mathrm{Y} 5$ receptors. This is consistent with our previous findings that selective activation of Y1 receptors did not modulate the release of glutamate in CA1 (23). However, in agreement with our glutamate release studies, this does not mean that $\mathrm{Y} 1$ or $\mathrm{Y} 5$ receptors are not active in CA1, but only suggests that they do not have a significant neuroprotective role in this subregion. Indeed, the distribution of mRNA for NPY receptors is not necessarily indicative of the distribution of the expressed proteins or binding sites. For example, there is for the Y5 receptor a clear lack of correlation between Y5 mRNA levels and binding sites in the human hypothalamus (48).

When kainate was applied as the excitotoxin, it mainly induced cell death in the CA3 pyramidal cell layer, and activation of Y1, Y2, or Y5 receptors was again neuroprotective. For the kainate- 
induced toxicity in CA1, only the $\mathrm{Y} 2$ receptor was neuroprotective. For CA3, we have previously reported that activation of $\mathrm{Y} 1$ and $\mathrm{Y} 2$ receptors inhibits glutamate release in a very similar way (23), just as Y5 receptors have been shown to mediate presynaptic inhibition of stratum radiatum-evoked glutamatergic responses in some CA3 neurons (45).

Under normal conditions, NPY is expressed only by GABAergic interneurons, but during excitotoxic conditions, the expression of NPY and different NPY receptors is increased $(19,20)$. Moreover, Van den Pol and collaborators (49) have demonstrated that glutamate-dependent activity is necessary for NPY to depress the intracellular $\mathrm{Ca}^{2+}$ concentration and the electrical activity of neurons. Given that NPY affects synaptic transmission and neuronal excitability, and that this effect is significantly mediated by its interaction with glutamatergic neurotransmission (3), we found important to clarify the involvement of different NPY receptors in the protection against excitotoxicity.

Along this study, we have demonstrated for the first time the neuroprotective action of Y1, Y2, and Y5 receptors against AMPA and kainate mediated neurodegeneration in different hippocampal subregions. Such knowledge of which NPY receptors mediate the actions of NPY in the dentate granule cell layer, CA1 and CA3 pyramidal cell layers may be important for pharmacological targeting in several pathologic conditions associated with glutamate receptor hyperactivation as dysfunction.

\section{ACKNOWLEDGMENTS}

We acknowledge Henri Doods (Boehringer Ingelheim Pharma KG) for generously provide us the BIIE0246. LY303070 was a kind gift of Lilly Research Laboratories. This work was supported by Foundation for Science and Technology, PRAXIS XXI Program, Portugal (Project PRAXIS XXI/2/2.1/SAU/1348/95 and Grant PRAXIS 18261/98).

The technical help of Randi Godskesen, Inge Nielsen, and Dorte Bramsen is gratefully acknowledged.

\section{REFERENCES}

1. Wettstein, J. G., Earley, B., and Juniens, J. L. (1995) Central nervous system pharmacology of neuropeptide Y. Pharmacol. Ther. 65, 397-414

2. Balasubramaniam, A. (1997) Neuropeptide Y family of hormones: receptor subtypes and antagonists. Peptides 18, 445-457

3. Vezzani, A., Sperk, G., and Colmers, W. F. (1999) Neuropeptide Y: emerging evidence for a functional role in seizure modulation. Trends Neurosci. 22, 25-30

4. Wan, C. P., and Lau, B. H. (1995) Neuropeptide Y receptor subtypes. Life Sci. 56, 10551064

5. Lee, C. C., and Miller, R. J. (1998) Is there really an NPY Y3 receptor? Regul. Pept. 7576, 71-78 
6. Michel, M. C., Beck-Sickinger, A., Cox, H., Doods, H. N., Herzog, H., Larhammar, D., Quirion, R., Schwartz, T., and Westfall, T. (1998) XVI. International union of pharmacology recommendations for the nomenclature of neuropeptide $\mathrm{Y}$, peptide $\mathrm{YY}$, and pancreatic polypeptide receptors. Pharmacol. Rev. 50, 143-150

7. Cabrele, C., Langers, M., Bader, R., Wieland, H. A., Doods, H. N., Zerbe, O., and BeckSickinger, A. G. (2000) The first selective agonist for the neuropeptide YY5 receptor increase food intake in rats. J. Biol. Chem. 46, 36043-36048

8. Wieland, H. A., Willim, K. D., and Doods, H. N. (1995) Receptor binding profile of NPY analogues and fragments in different tissues and cell lines. Peptides 16, 1389-1394

9. Doods, H., Gaida, W., Wieland, H. A., Dollinger, H., Schnorrenberg, G., Esser, F., Engel, W., Eberlein, W., and Rudolf, K. (1999) BIIB0246: A selective and high affinity neuropeptide Y Y2 receptor antagonist. Eur. J. Pharmacol. 384, R3-R5

10. Kanatani, A., Ishibara, A., Iwaasa, H., Nakamura, K., Okamoto, O., Hidaka, M., Ito, J., Fukuroda, T., MacNeil, D. J., Van der Ploeg, L. H., et al. (2000) L-152,804: orally active and selective neuropeptide Y Y5 receptor antagonist. Biochem. Biophys. Res. Commun. 272, 169173

11. Parker, R. M. C., and Herzog, H. (1999) Regional distribution of Y-receptor subtype mRNA in rat brain. Eur. J. Neurosci. 11, 1431-1448

12. Jacques, D., Dumont, Y., Fournier, A., and Quirion, R. (1997) Characterization of neuropeptide $\mathrm{Y}$ receptor subtypes in the normal human brain, including the hypothalamus. Neuroscience 79, 5804-5812

13. Dumont, Y., Fournier, A., and Quirion, R. (1998) Expression and characterization of the neuropeptide $\mathrm{Y}_{5}$ receptor subtype in the rat brain. J. Neurosci. 18, 5565-5574

14. Grove, K. L., Campbell, R. E., Ffrench-Mullen, J. M. H., Cowley, M. A., and Smith, M. S. (2000) Neuropeptide Y Y5 receptor protein in the cortical/limbic system and brainstem of the rat: expression on $\gamma$-aminobutyric acid and corticotropin-releasing hormone neurons. Neuroscience 100, 731-740

15. Bijak, M. (1999) Neuropeptide Y suppresses epileptiform activity in rat frontal cortex and hippocampus in vitro via different NPY receptor subtypes. Neurosci. Lett. 268, 115-118

16. Furtinger, S., Pirker, S., Czech, T., Baumgartner, C., Ransmay, G., and Sperk, G. (2001) Plasticity of Y1 and Y2 receptors and neuropeptide $\mathrm{Y}$ fibers in patients with temporal lobe epilepsy. J. Neurosci. 21, 5804-5812

17. Woldbye, D. P. D., Larsen, P. J., Mikkelsen, J. D., Klemp, K., Madsen, T. M., and Bolwig, T. G. (1997) Powerful inhibition of kainic acid seizures by neuropeptide Y via Y5-like receptors. Nat. Med. 3, 761-764 
18. Marsh, D. J., Baraban, S. C., Hollopeter, G., and Palmiter, R. D. (1999) Role of the Y5 neuropeptide Y receptor in limbic seizures. Proc. Natl. Acad. Sci. USA 96, 13518-13523

19. Schwarzer, C., Sperk, G., Rizzi, M., Gariboldi, M., and Vezzani, A. (1996) Neuropeptides-immunoractivity and their mRNA expression in kindling: functional implications for limbic epileptogenesis. Brain Res. Brain Res. Rev. 22, 27-50

20. Takahashi, Y., Tsunashima, K., Sadamatsu, M., Schwarzer, C., Amano, S., Ihara, N., Sasa, M., Kato, N., and Sperk, G. (2000) Altered hippocampal expression of neuropeptide Y, somastotatin, and glutamate decarboxylase in Ihara's epileptic rats and spontaneously epileptic rats. Neurosci. Lett. 287, 105-108

21. Baraban, S. C., Hollopeter, G., Erikson, J. C., Schwartzkroin, P. A., and Palmiter, R. D. (1997) Knock-out mice reveal a critical antiepileptic role for neuropeptide Y. J. Neurosci. 17, $8927-8936$

22. McCullough, L. A., Egan, T. M., and Westfall, T. C. (1998) Neuropeptide Y receptors involved in calcium channel regulation in PC12 cells. Regul. Pept. 75-76, 101-107

23. Silva, A. P., Malva, J. O., Ambrósio, A. F., Salgado, A. J., Carvalho, A. P., and Carvalho, C. M. (2001a) Role of kainate receptor activation and desensitization on the $\left[\mathrm{Ca}^{2+}\right]_{i}$ changes in cultured rat hippocampal neurons. J. Neurosci. Res. 65, 378-386

24. Klapstein, G. J., and Colmers, W. F. (1997) Neuropeptide Y suppresses epileptiform activity in rat hippocampus in vitro. $J$. Neurophysiol. 78, 1651-1661

25. Stoppini, L., Buchs, P. A., and Muller, D. (1991) A simple method for organotypic cultures of nervous tissue. J. Neurosci. Methods 37, 173-182

26. Kristensen, B. W., Noraberg, J., Jakobsen, B., Gramsbergen, J. B., Ebert, B., and Zimmer, J. (1999) Excitotoxic effects of non-NMDA receptor agonists in organotypic corticostriatal slice cultures. Brain Res. 841, 143-159

27. Noraberg, J., Kristensen, B. W., and Zimmer, J. (1999) Markers for neuronal degeneration in organotypic slice cultures. Brain Res. Brain Res. Protoc. 3, 278-290

28. Kristensen, B. W., Noraberg, J., and Zimmer, J. (2001) Comparison of excitotoxic profiles of ATPA, AMPA, KA and NMDA in organotypic hippocampal slice cultures. Brain Res. 917, 21-44

29. Silva, A. P., Carvalho, A. P., Carvalho, C. M., and Malva, J. O. (2001b) Modulation of intracellular calcium changes and glutamate release by neuropeptide $\mathrm{Y} 1$ and $\mathrm{Y} 2$ receptors in the rat hippocampus: differential effects in CA1, CA3 and dentate gyrus. J. Neurochem. 79, 286-296

30. Hsu, S. S., Newell, D. W., Tucker, A., Malouf, A. T., and Winn, H. R. (1994) Adenosinergic modulation of CA1 neuronal tolerance to glucose deprivation in organotypic hippocampal cultures. Neurosci. Lett. 178, 189-192 
31. Pozzo Miller, L. D., Mahanty, N. K., Connor, J. A., and Landis, D. M. (1994) Spontaneous pyramidal cell death in organotypic slice cultures from rat hippocampus is prevented by glutamate receptor antagonists. Neuroscience 63, 471-487

32. Vitale, M., Zamai, L., Mazzoti, G., Cataldi, A., and Falcieri, E. (1993) Differential kinetics of propidium iodide uptake in apoptotic and necrotic thymocytes. Histochemistry 100, $223-229$

33. Pringle, A. K., Iannotti, F., Wilde, L. R., Chad, J. E., Seeley, P. J., and Sundstrom, L. E. (1997) Neuroprotection by both NMDA and non-NMDA receptor antagonists in vitroischemia. Brain Res. 755, 36-46

34. Lees, G. J., and Leong, W. (1993) Differential effects of NBQX on the distal and local toxicity of glutamate agonists administered intra-hippocampally. Brain Res. 628, 1-7

35. Ambrósio, A. F., Silva, A. P., Malva, J. O., Mesquita, J. F., Carvalho, A. P., and Carvalho, C. M. (2000) Role of desensitization of AMPA receptors on the neuronal viability and on the $\left[\mathrm{Ca}^{2+}\right]_{\mathrm{i}}$ changes in cultured rat hippocampal neurons. Eur. J. Neurosci. 12, 2021-2031

36. Casaccia Bonnefil, P., Benedikz, E., Rai, R., and Bergold, P. J. (1993) Excitatory and inhibitory pathways modulate kainate excitotoxicity in hippocampal slice cultures. Neurosci. Lett. 154, 5-8

37. Malva, J. O., Carvalho, A. P., and Carvalho, C. M. (1998) Kainate receptors in hippocampal CA3 subregion: evidence for a role in regulating neurotransmitter release. Neurochem. Int. 32, 1-6

38. Chittajallu, R., Braithwaite, S. P., Clarke, V. R., and Henley, J. M. (1999) Kainate receptors:subunits, synasptic localization and function. Trends Pharmacol. Sci. 20, 26-35

39. Paternain, A. V., Morales, M., and Lerma, J. (1995) Selective antagonism of AMPA receptors unmasks kainate receptor-mediated responses in hippocampal neurons. Neuron 14, $185-189$

40. Larm, J. A., Cheung, N. S., and Beart, P. M. (1997) Apoptosis induced via AMPAselective glutamate receptors in cultured murine cortical neurons. J. Neurochem. 69, 617-622

41. Fujikawa, D. G., Shinmei, S. S., and Cai, B. (2000) Kainic acid-induced seizures produce necrotic, not apoptotic neurons with internucleosomal DNA cleavage: implications for programmed cell death mechanisms. Neuroscience 98, 41-53

42. Ankarcrona, M., Dypburkt, J. M., Bonfoco, E., Zhivotousky, B., Orreni, S., Lipton, A. S., and Nicotera, P. (1995) Glutamate-induced neuronal death: a succession of necrosis or apoptosis depending on mitochondrial function. Neuron 15, 961-973

43. Whittaker, E., Vereker, E., and Lynch, M. A. (1999) Neuropeptide Y inhibits glutamate release and long-term potentiation in rat dentate gyrus. Brain Res. 827, 229-233 
44. Patrylo, P. R., Van Den Pol, A. N., Spencer, D. D., and Williamson, A. (1999) NPY inhibits glutamatergic excitation in the epileptic human dentate gyrus. J. Neurophysiol. 82, 478483

45. Ho, M. W. Y., Beck-Sickinger, A. G., and Colmers, W. F. (2000) Neuropeptide $Y_{5}$ receptors reduce synaptic excitation in proximal subiculum, but not epileptiform activity in rat hippocampal slices. J. Neurophysiol. 83, 723-734

46. McQuiston, A. R., and Colmers, W. F. (1996) Neuropeptide $Y_{2}$ receptors inhibit the frequency of spontaneous but not miniature EPSCs in CA3 pyramidal cells of rat hippocampus. J. Neurophysiol. 76, 3159-3168

47. Bacci, A., Huguenard, J. R., and Prince, D. A. (2002) Differential modulation of synaptic transmission by neuropeptide $\mathrm{Y}$ in rat neocortical neurons. Proc. Natl. Acad. Sci. USA 99, $17125-17130$

48. Statnick, M. A., Douglas, A. S., Gackenheimer, S., Johnson, D., Beavers, L., Mayne, N. G., Burnett, J. P., Gadski, R., and Gehlert, D. R. (1998) Characterization of the neuropeptide Y5 receptor in the human hypothalamus: a lack of correlation between Y5 mRNA levels and binding sites. Brain Res. 810, 16-26

49. Van den Pol, A. N., Obrietan, K., Chen, G., and Belousov, A. B. (1996) Neuropeptide Ymediated long-term depression of excitatory activity in suprachiasmatic nucleus neurons. $J$. Neurosci. 16, 5883-5895 
Fig. 1

Exposure to NPY ligands

- - Exposure to $2 \mu \mathrm{M}$ AMPA or $6 \mu \mathrm{M} \mathrm{KA}$

$\longrightarrow$ Addition of PI to the medium

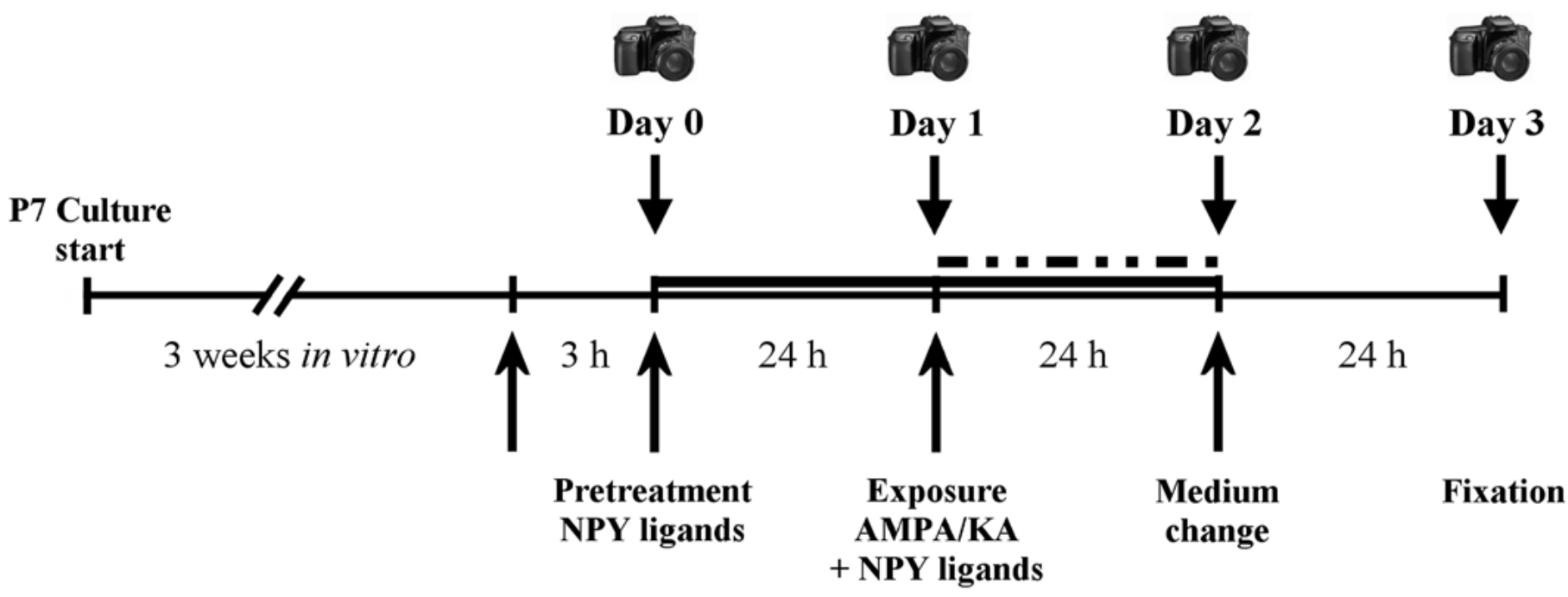

Figure 1. Experimental protocol for investigating the potential neuroprotective effects of neuropeptide $Y$

receptors in hippocampal slice cultures. Propidium iodide (PtdIns) was used as a marker for cell death. Donor tissue: P7 hippocampus. For details, see text. 
Fig. 2

A

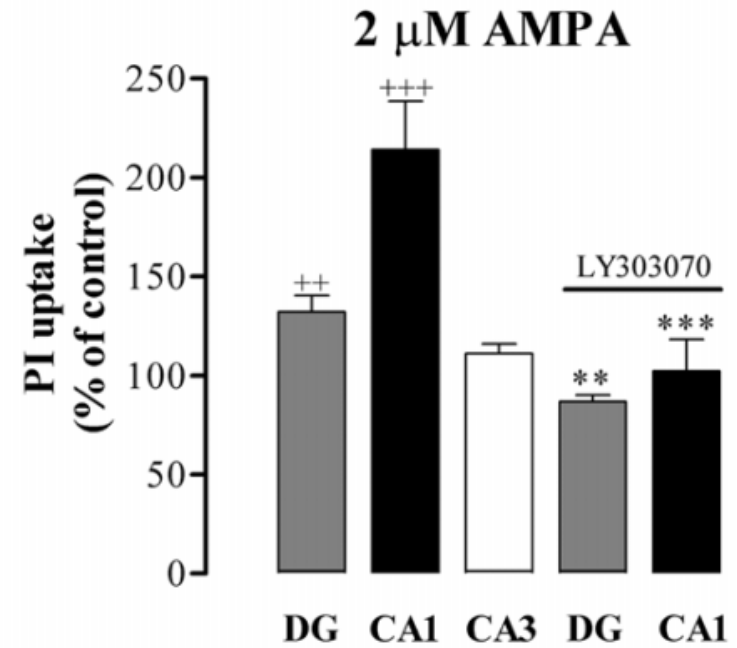

B

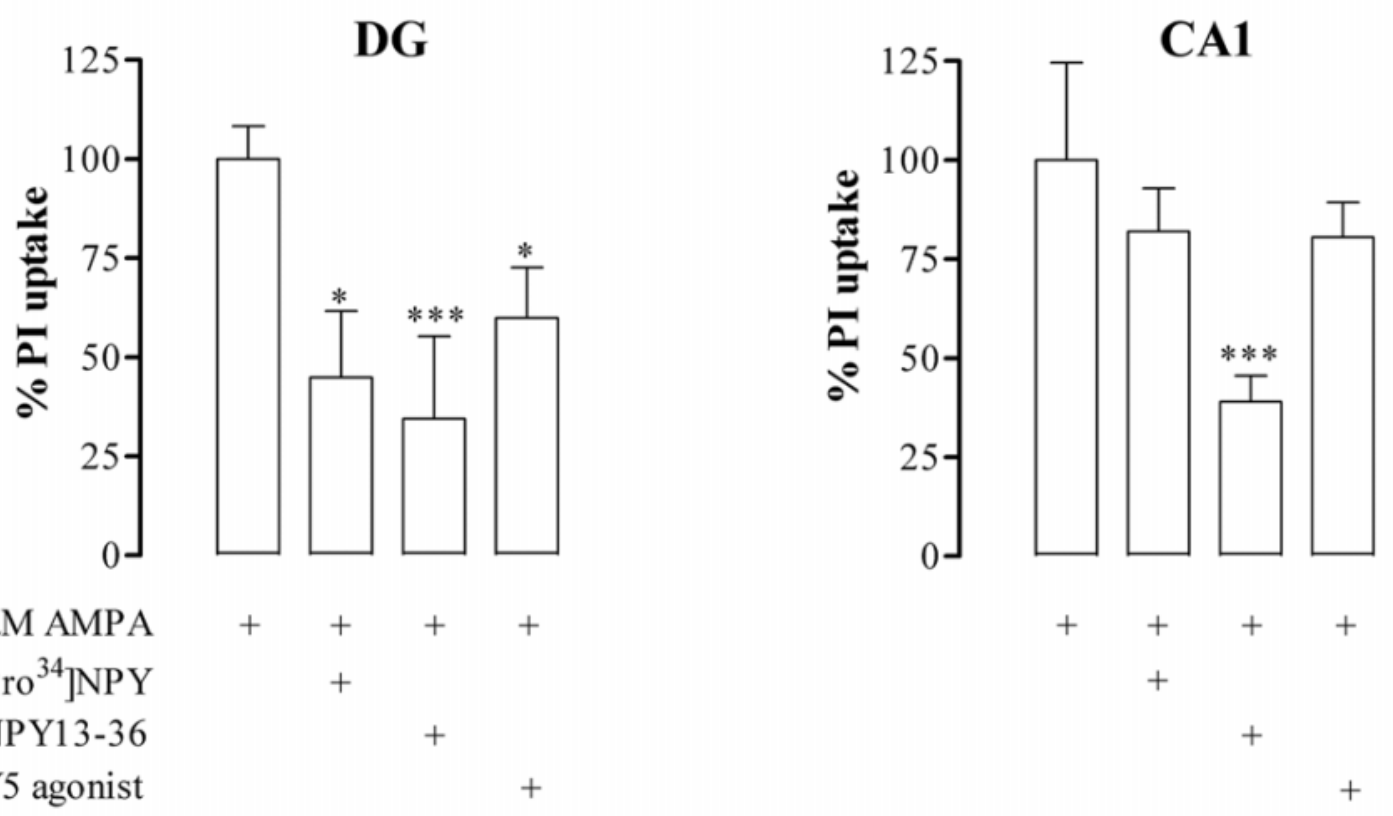

Figure 2. AMPA-induced cell degeneration in the dentate granule cell layer and CA1 pyramidal cell layer, and neuroprotection by NPY receptor activation. A) Densitometric measurements of propidium iodide (PtdIns) uptake induced by $2 \mu \mathrm{M}$ AMPA in dentate granule cell layer (DG), CA1 and CA3 pyramidal cell layers, and effect of LY303070 $(15 \mu \mathrm{M})$ on the toxicity induced by AMPA in both dentate granule cell layer and CA1 pyramidal cell layer. Effect of Y1 $\left(1 \mu \mathrm{M}\left[\mathrm{Leu}^{31}{ }^{\text {,Pro }}{ }^{34}\right] \mathrm{NPY}\right), \mathrm{Y} 2$ (300 nM NPY13-36), or Y5 receptor agonist (500 nM NPY(19-23)$\left(\mathrm{Gly}^{1}{ }^{,} \mathrm{Ser}^{3}, \mathrm{Gln}^{4}, \mathrm{Thr}^{6}, \mathrm{Ala}^{31}, \mathrm{Aib}^{32}, \mathrm{Gln}^{34}\right)$-PP) on the PtdIns uptake induced by $2 \mu \mathrm{M}$ AMPA in (B) the dentate granule cell layer or (C) CA1 pyramidal cell layer. In (A) the PtdIns uptake determined after $24 \mathrm{~h}$ is expressed as a percentage of control. In $(\mathbf{B})$ and $(\mathbf{C})$ the PtdIns uptake induced by $2 \mu \mathrm{M}$ AMPA was set to $100 \%$. Data are shown as means \pm SEM with $n=14-66$. A) ${ }^{++} P<0.01,{ }^{++} P<0.001$ using $t$-test for comparison with control (no drugs exposure), and $* * P<0.01$, $* * * P<0.001$ using ANOVA with Bonferroni correction for comparison with the effect of $2 \mu \mathrm{M}$ AMPA in DG and CA1, respectively. B, C) $* P<0.05, * * * P<0.001$ using Dunnett's correction for comparison with control ( $2 \mu \mathrm{M}$ AMPA). 
Fig. 3
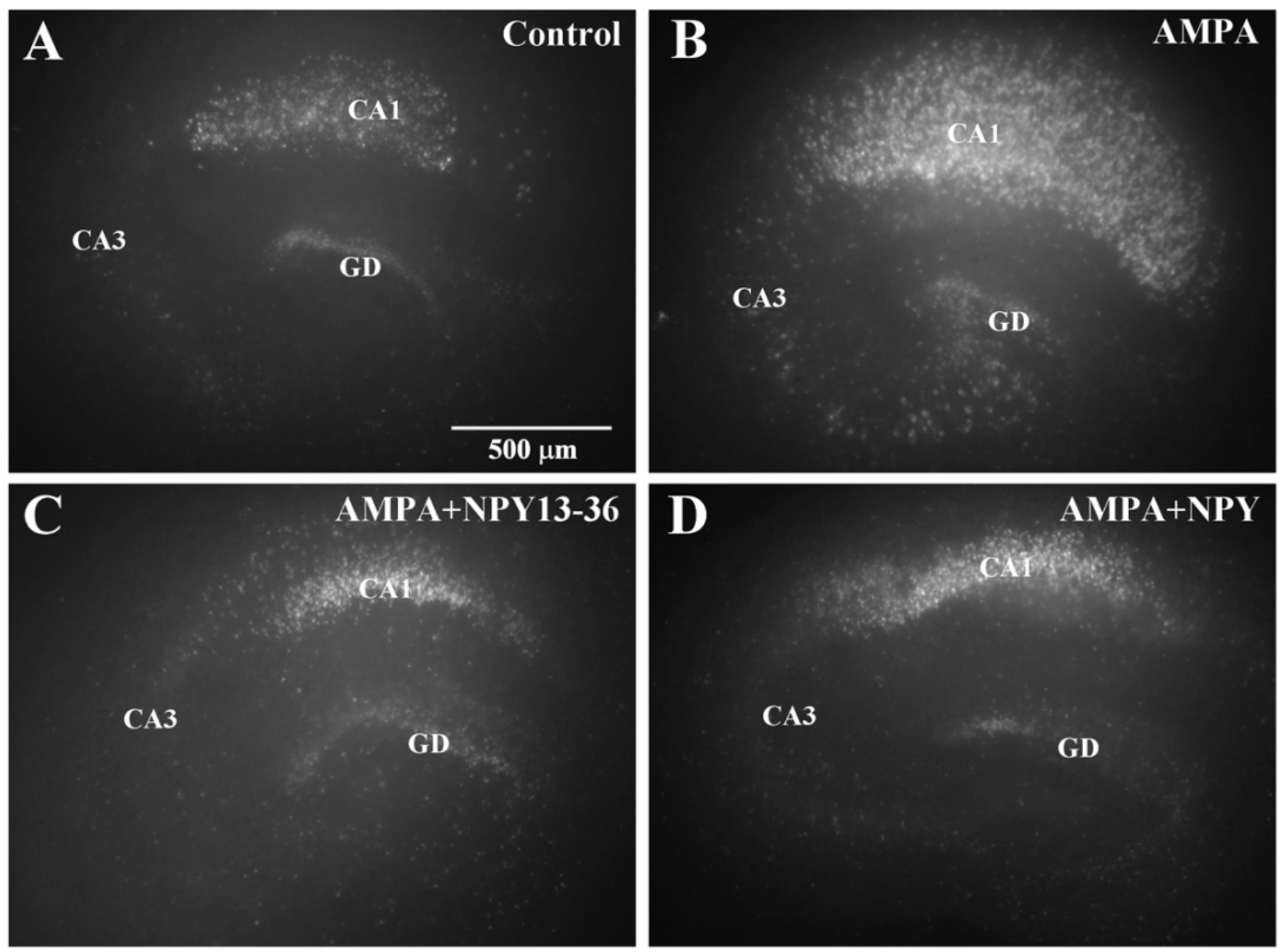

Figure 3. Fluorescent microscope digital images of PtdIns uptake in hippocampal cultures derived from 7-day-old rats and grown for 3 weeks. A) Control culture with low basal PtdIns uptake. B) Culture exposed to $2 \mu \mathrm{M}$ AMPA with increase in PtdIns uptake in the CA1 pyramidal cell layer. Culture co-exposed to (C) $2 \mu \mathrm{M}$ AMPA and $300 \mathrm{nM}$ NPY1336 (Y2 receptor agonist) or to (D) $2 \mu \mathrm{M}$ AMPA and $1 \mu \mathrm{M}$ NPY (endogenous NPY receptor agonist). Scale bar, $500 \mu \mathrm{m}$. 
Fig. 4

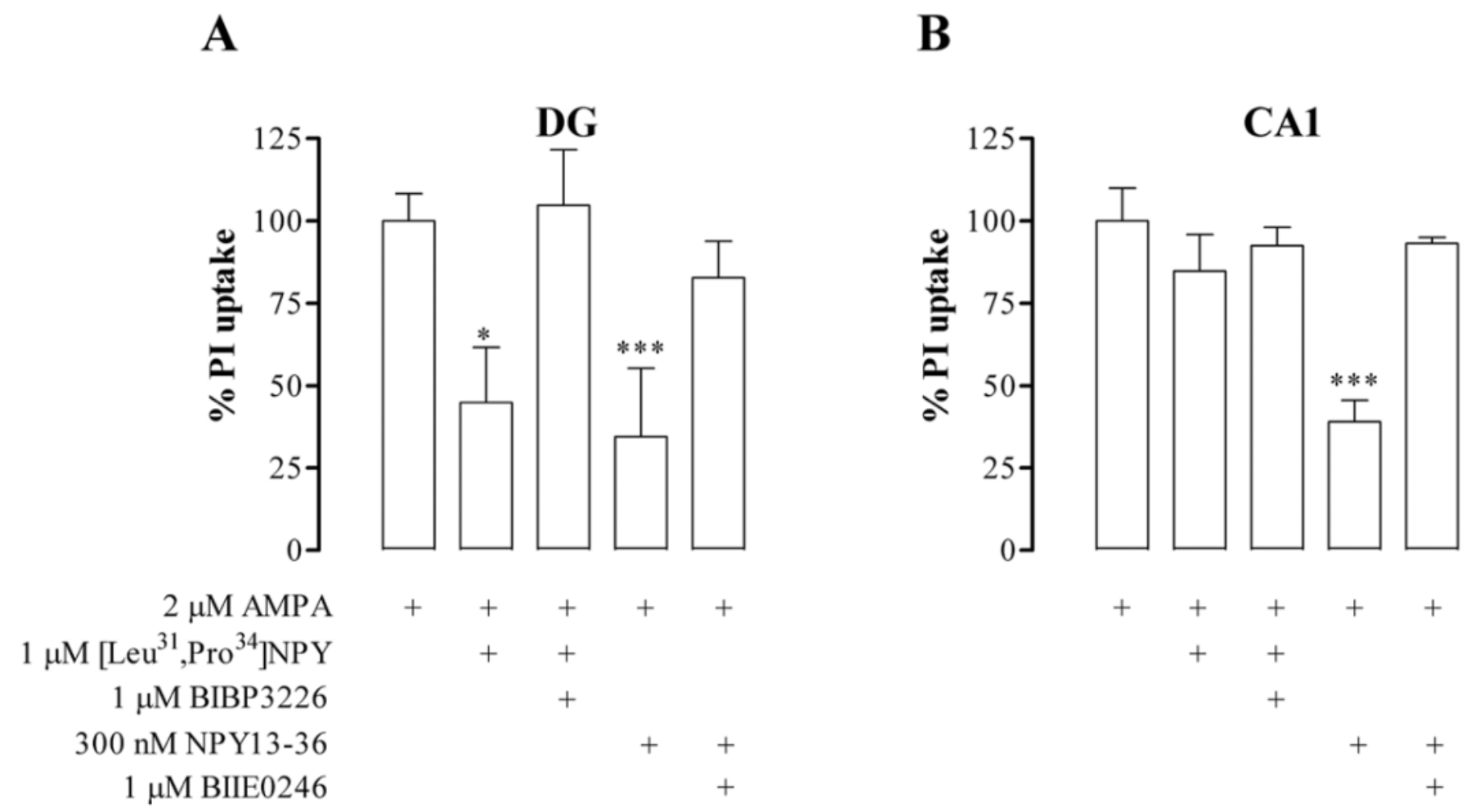

Figure 4. Blockade of Y1 or Y2 receptor-mediated neuroprotection by selective antagonists of the receptors subtypes. Effect of $1 \mu \mathrm{M}$ BIBP3226 or $1 \mu \mathrm{M}$ BIIE0246, the Y1 or Y2 receptor antagonist, respectively, on the PtdIns uptake induced by $2 \mu \mathrm{M}$ AMPA plus Y1 or Y2 receptor agonist in (A) the dentate granule cell layer or (B) CA1 pyramidal cell layer. The PtdIns uptake induced by AMPA was set to $100 \%$. Data are shown as mean \pm SEM, with $n=12-$ 21 and $* P<0.05, * * * P<0.001$ by using Dunnett's correction for comparison with control ( $2 \mu \mathrm{M}$ AMPA). 
Fig. 5
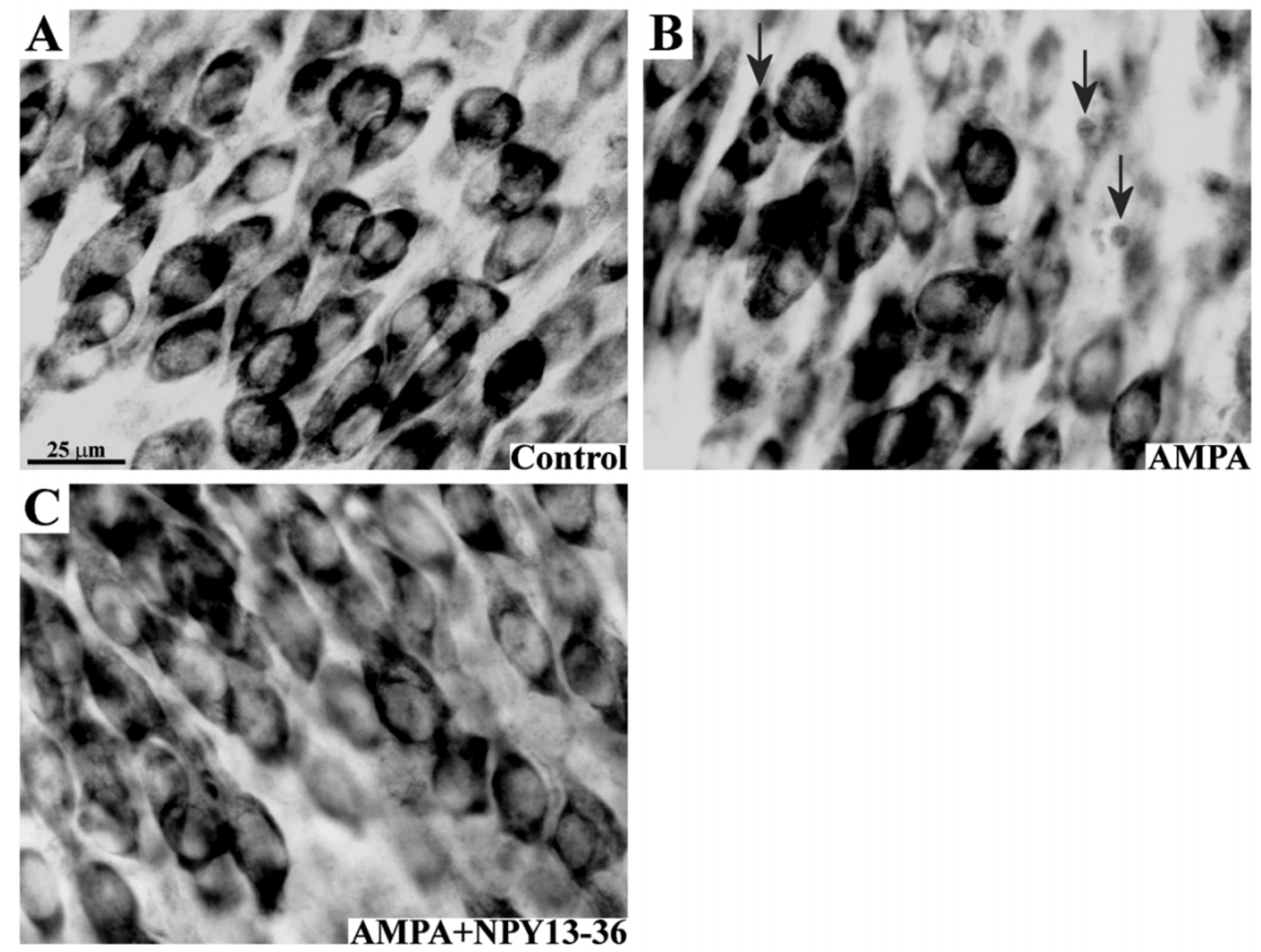

Figure 5. Evaluation of the morphological changes of CA1 pyramidal cells after an excitotoxic insult with AMPA, in the absence or in the presence of an Y2 receptor agonist. A) Toluidine blue-stained 3-week-old hippocampal slice culture in a control situation. Cultures exposed to (B) $2 \mu \mathrm{M}$ AMPA for $24 \mathrm{~h}$, followed by $24 \mathrm{~h}$ recovery, or to (C) $2 \mu \mathrm{M}$ AMPA plus $300 \mathrm{nM}$ NPY13-36 for $24 \mathrm{~h}$, followed by $24 \mathrm{~h}$ recovery (pre-incubation with NPY13-36 during $24 \mathrm{~h}$ ). B) The CA1 pyramidal cells displayed degenerative features with darkly stained nuclei, which are not frequently found in (A) control situation or in $(\mathbf{C})$ the presence of the Y2 receptor agonist. Arrows indicate apoptotic-like neurons. High magnification of the CA1 pyramidal cell layer $(\times 500)$. Scale bar, $25 \mu \mathrm{m}$. 
Fig. 6

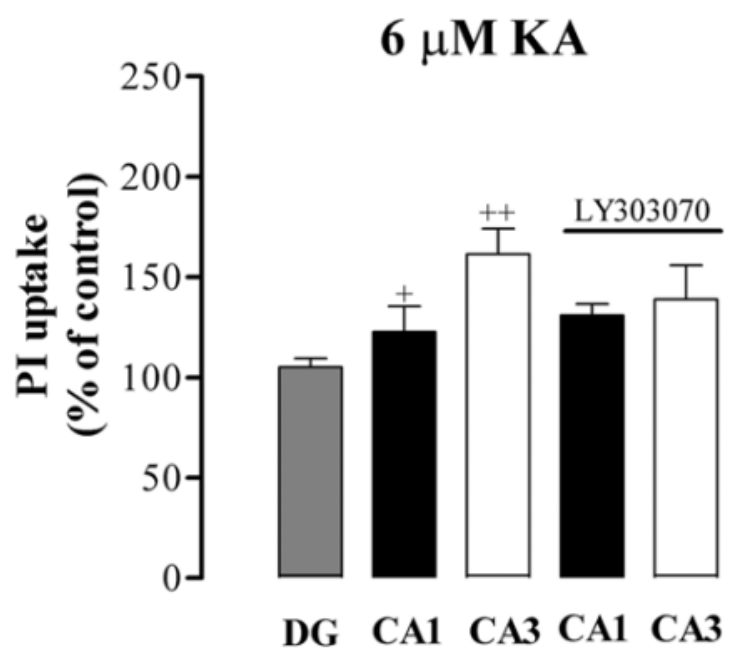

B

C
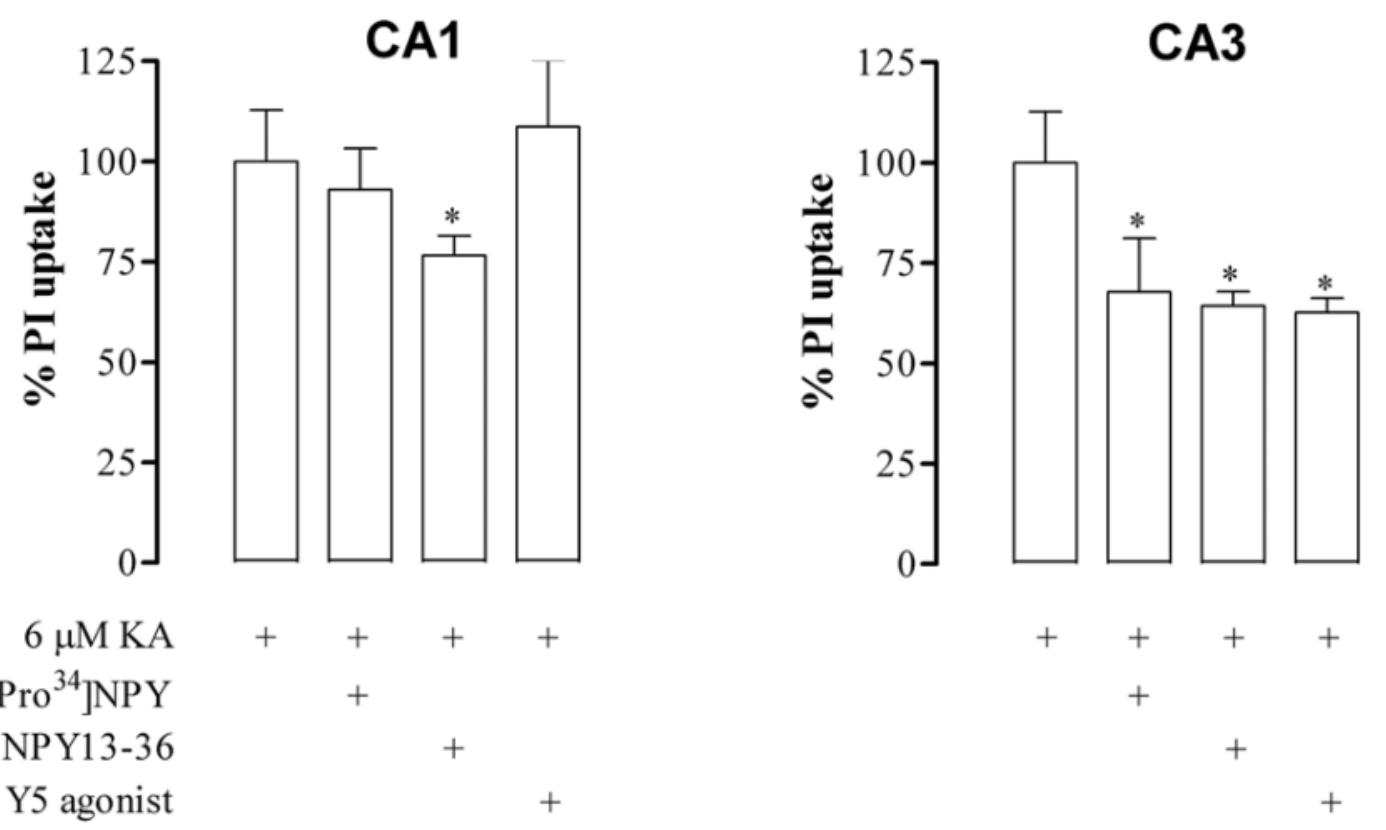

Figure 6. Kainate-induced cell degeneration in the CA1 and CA3 pyramidal cell layers and neuroprotection by NPY receptor activation. A) Densitometric measurements of propidium iodide (PtdIns) uptake induced by $6 \mu \mathrm{M}$ KA in dentate granule cell layer (DG), CA1 and CA3 pyramidal cell layers, and effect of LY303070 (15 $\mu \mathrm{M})$ on the toxicity induced by kainate in CA1 and CA3 pyramidal cell layers. B, C) Effect of Y1 (1 $\mu$ M [Leu ${ }^{31}$,Pro $\left.\left.{ }^{34}\right] \mathrm{NPY}\right)$, Y2 (300 nM NPY13-36) or Y5 receptor agonist (500 nM NPY(19-23)-( $\left.\mathrm{Gly}^{1}{ }^{,} \mathrm{Ser}^{3}, \mathrm{Gln}^{4}, \mathrm{Thr}^{6}, \mathrm{Ala}^{31}, \mathrm{Aib}^{32}, \mathrm{Gln}^{34}\right)$-PP) on the PtdIns uptake induced by $6 \mu \mathrm{M}$ KA in (B) CA1 and (C) CA3 pyramidal cell layers. In A) the PtdIns uptake recorded after $24 \mathrm{~h}$ is expressed as a percentage of control. In $(\mathbf{B}$ and $\mathbf{C})$ the PtdIns uptake induced by kainate was set to 100\%. Data are shown as mean \pm SEM with $n=18-33$. A) ${ }^{+} P<0.05,{ }^{++} P<0.01$ by using $t$-test for comparison with control (no drugs exposure). B, C) $* P<0.05$ by using Dunnett's correction for comparison with control (6 $\mu \mathrm{M} \mathrm{KA})$. 
Fig. 7
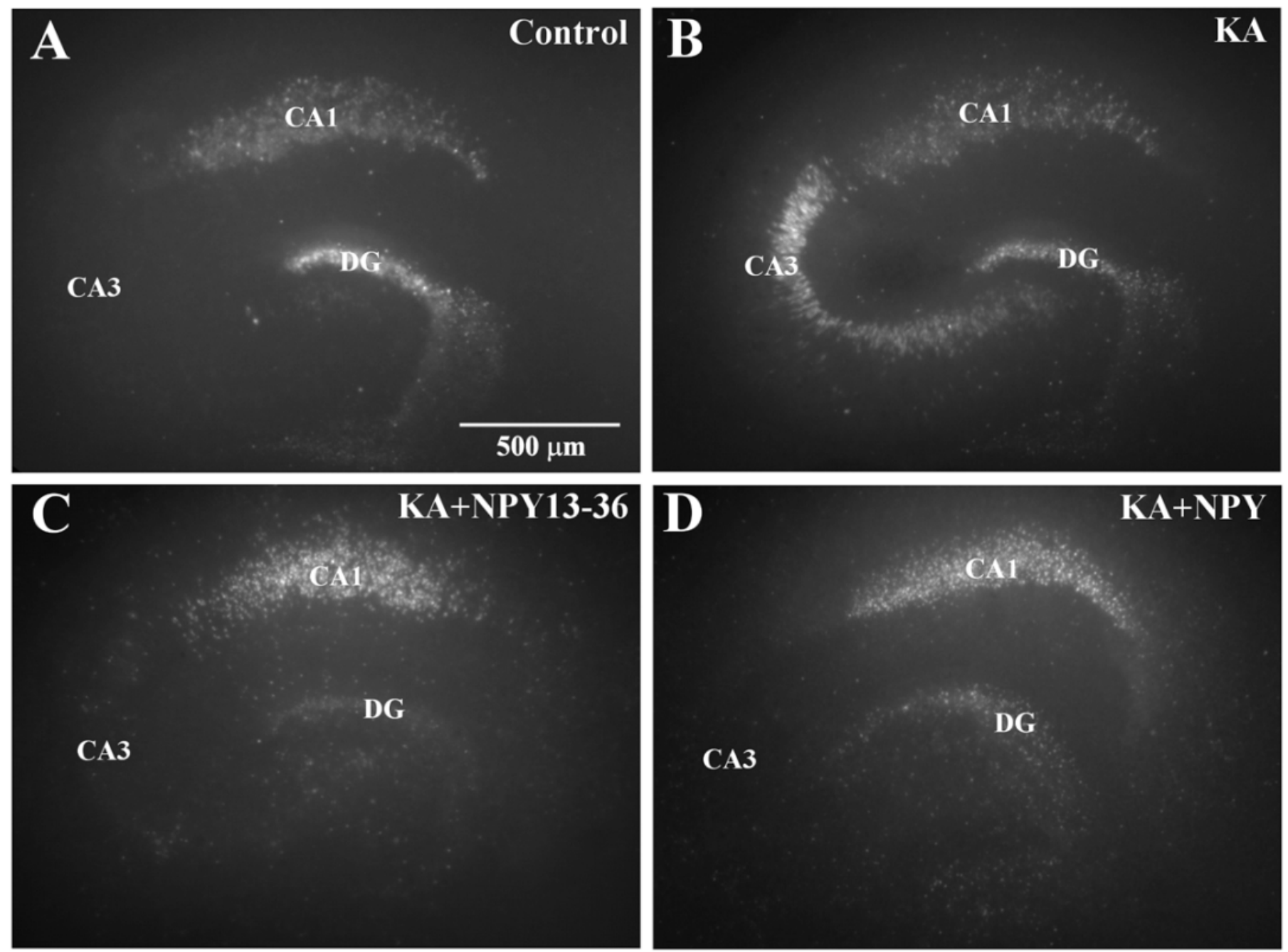

Figure 7. Fluorescent microscope digital images of propidium iodide (PtdIns) uptake in hippocampal cultures derived from 7-day-old rats and grown for 3 weeks. A) Control culture with low basal PtdIns uptake. B) Culture exposed to $6 \mu \mathrm{M}$ KA with increase in PtdIns uptake in the CA3 pyramidal cell layer. Culture with clearly inhibited PtdIns uptake after co-exposure to (C) $6 \mu \mathrm{M} \mathrm{KA}$ and $300 \mathrm{nM}$ NPY13-36 (Y2 receptor agonist) or to (D) $6 \mu \mathrm{M}$ KA and $1 \mu \mathrm{M}$ NPY (endogenous NPY receptor agonist). Scale bar, $500 \mu \mathrm{m}$. 
Fig. 8
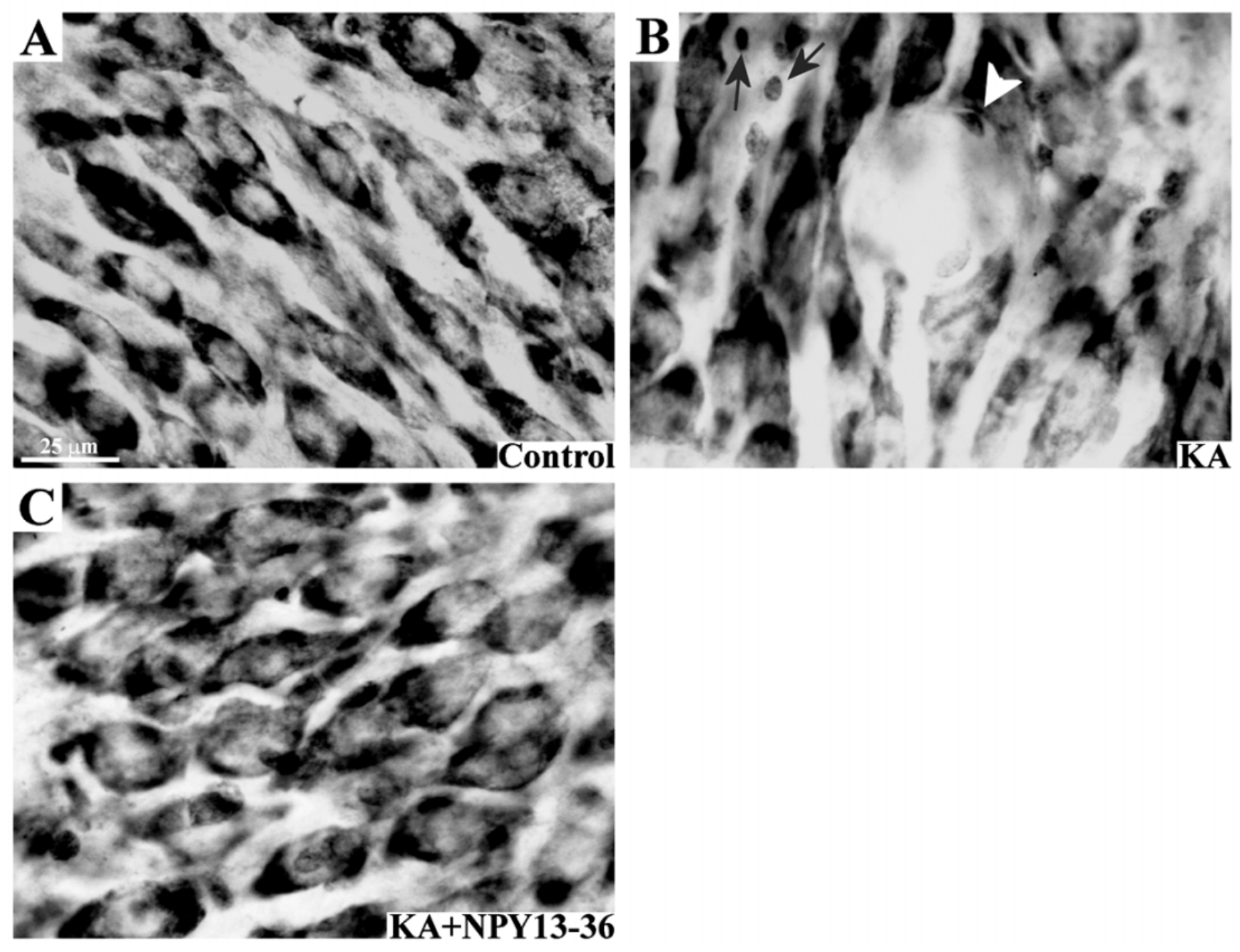

Figure 8. Morphological characteristics of CA3 pyramidal cells after an excitotoxic insult with KA in the absence or in the presence of an Y2 receptor agonist. A) Toluidine blue stained 3-week-old hippocampal slice culture in a control condition. Cultures exposed to (B) $6 \mu \mathrm{M}$ KA for $24 \mathrm{~h}$, followed by $24 \mathrm{~h}$ recovery, or to (C) $6 \mu \mathrm{M}$ KA plus $300 \mathrm{nM}$ NPY13-36 for $24 \mathrm{~h}$, followed $24 \mathrm{~h}$ recovery (pre-incubation with NPY13-36 during $24 \mathrm{~h}$ ). In (B) some of the CA3 pyramidal cells show a necrotic- (arrowhead) or apoptotic-like morphology (arrows), which are not frequently found in (A) control situation or in $(\mathbf{C})$ the presence of NPY13-36. High magnification of the CA3 pyramidal cell layer $(\times 500)$. Scale bar, $25 \mu \mathrm{m}$. 